\title{
Hubungan Antara Pola Asuh Orang Tua dan Konsep Diri dengan Kompetensi Pengetahuan Matematika Siswa
}

\author{
* Ni Komang Riski Juniarti¹, I Gede Margunayasa², Nyoman Kusmariyatni ${ }^{3}$ \\ ${ }^{123}$ Prodi PGSD, Jurusan Pendidikan Dasar, FIP, Universitas Pendidikan Ganesha,Singaraja,Indonesia
}

A R T I C L E I N F O

Article history:

25 December 2019

Received in revised form

01 January 2020

Accepted 25 January 2020

Available online 28

February 2020

Kata Kunci:

matematika, konsep diri,

pola asuh orang tua

Keywords:

mathematic, self concept,

parenting style

dan konsep diri dengan kompetensi kompetensi pengetahuan matematika siswa kelas V SD di Gugus I Kecamatan Baturiti. Jenis penelitian ini adalah penelitian ex post facto. Populasi dari penelitian ini berjumlah 144 siswa dengan jumlah sampel sebanyak 100 siswa diambil dengan teknik proportional random sampling. Pengujian hipotesis menggunakan regresi sederhana dan regresi ganda. Berdasarkan hasil pengujian hipotesis menunjukkan bahwa terdapat hubungan yang positif dan signifikan pola asuh orang tua dengan kompetensi pengetahuan matematika $(r=0,570)$, terdapat hubungan yang positif dan signifikan konsep diri dengan kompetensi pengetahuan matematika( $r=$ 0,502), dan terdapat hubungan yang positif dan signifikan antara pola asuh orang tua dan konsep diri dengan kompetensi pengetahuan matematika siswa kelas V di SD Gugus I Kecamatan Baturiti $(R=$ $0,741)$.

\section{A B S T R A C T}

Parenting is a factor that influences students' learning success in self-concept. It is one of several internal factors that can affect achievement in learning mathematic. The cause of the lack optimal values in the competence of mathematic knowledge is the difference in student characteristics, especially the speed of processing information provided by the teacher during learning. When learning takes place, most students were inactive because when teachers ask questions students did not respond and the difficulty of students to concentrate on learning. This research aimed to determine the relationship of parenting with mathematic knowledge competence, the relationship between selfconcept and mathematic knowledge competence and the relationship between parenting and selfconcept with the mathematics knowledge competence on fifth grade elementary school students in Cluster I of Baturiti District. The population of this research was 144 students with the total sample amount of 100 students taken with proportional random sampling technique. Hypothesis testing used simple regression and multiple regressions. Based on the results of hypothesis testing showed that there was a positive and significant relationship between parenting and mathematics knowledge competence $(r=0.570)$, there was a positive and significant relationship between self-concept and mathematic knowledge competence ( $r=0.502)$, and there was a positive and significant relationship between parenting and self-concept with mathematics knowledge competence on fifth grade students in Elementary School Cluster I of Baturiti District $(R=0.741)$.

Copyright (C) Universitas Pendidikan Ganesha. All rights reserved 


\section{Pendahuluan}

Matematika merupakan salah satu disiplin ilmu yang dapat meningkatkan kemampuan berpikir dan beragumentasi, memberikan kontribusi dalam penyelesaian masalah sehari-hari dan dunia kerja, serta memberikan dukungan dalam mengembangkan ilmu pengetahuan dan teknologi(Susanto, 2013) Mata pelajaran matematika pada jenjang pendidikan sekolah dasar untuk kelas IV, V, dan VI tidak termasuk pembelajaran menggunakan tema atau tematik terpadu, melainkan mata pelajaran yang berdiri sendiri (Permendikbud No. 24 Tahun 2016). "Dibelajarkannya matematika dimulai dari tingkat sekolah dasar untuk membekali siswa berbagai kemampuan seperti: kemampuan berpikir logis, analitis, sistematis, kritis dan kreatif serta kemampuan bekerjasama"(Japa, I .G.N dan Suarjana, 2015).

Siswa sebagai salah satu komponen dalam pendidikan harus selalu dilatih melalui pembiasaan berpikir mandiri untuk memecahkan masalah. Melalui mata pelajaran matematika diharapkan dapat membantu siswa agar tertata nalarnya, terbentuk kepribadiannya, dan terampil menggunakan matematika maupun penalaran dalam kehidupannya kelak (Dipayana, 2014). Matematika juga dapat melatih siswa agar mampu berpikir secara logis, analitis, kritis, cermat, sistematis, dan kreatif yang dapat meningkatkan hasil belajar siswa(Yuda, 2013). Hasil belajar merupakan seperangkat kompetensi pembelajaran yang mencakup tiga kompetensi yaitu kompetensi kognitif, afektif, dan psikomotor. Namun di sisi lain, kompetensi pembelajaran juga mencakup aspek spiritual. Berdasarkan hal ini, hasil belajar matematika mencakup aspek ranah kompetensi kognitif, afektif, psikomotor, dan spiritual yang dikuasai setelah melalui proses pembelajaran (Susanto, 2013;Kosasih, 2014).

Berdasarkan survei yang dilakukan oleh Programme For International Student Assesmen (PISA), Organization For Economic Cooperation and Development (OCED) mengemukakan bahwa Indonesia menempati peringkat 69 dari 76 negara dibidang matematika(Fathani, 2016), hal ini membuktikan bahwa kompetensi pengetahuan matematika belum optimal. Kegiatan lain seperti pencatatan dokumen dan wawancara yang dilakukan selama dua hari dimulai dari tanggal 29 sampai dengan 30 November 2018 di SD Gugus I Kecamatan Baturiti. Diperoleh informasi yang menunjukkan hal yang sama dengan survei yang dilakukan.

Berdasarkan pencatatan dokumen dilaksanakan pada siswa kelas V di SD Gugus I Kecamatan Baturiti, sebanyak 52,08\% siswa yang belum mencapai KKM. Hal ini ditunjukkan dengan nilai hasil ulangan akhir semester ganjil siswa pada kompetensi pengetahuan matematika. Berdasarkan wawancara dengan beberapa guru kelas V diketahui bahwa guru sudah menggunakan pendekatan saintifik dalam pembelajaran walaupun terkadang fokus guru masih pada pencapaian target materi. Penyebab kurang optimalnya nilai pada kompetensi pengetahuan matematika yaitu perbedaan karakteristik siswa terutama kecepatan memproses informasi yang diberikan oleh guru pada saat pembelajaran. Pada saat pembelajaran berlangsung sebagian besar siswa dikatakan tidak aktif hal ini disebabkan ketika guru mengajukan pertanyaan siswa tidak merespon dan sulitnya siswa berkonsentrasi pada saat pembelajaran. Selain itu, terdapat sebanyak 21 siswa tidak mengerjakan dan mengumpulkan tugas tepat pada waktu yang telah ditentukan. Selain mewawancarai guru, siswa juga turut diwawancarai dengan diperoleh informasi bahwa siswa di rumah hanya belajar apabila ada tugas serta kurang mendapatkan pengawasan saat belajar karena orang tua yang sibuk bekerja, orang tua juga mendukung ketidakhadiran siswa ketika ada acara dan kurangnya kesadaran orang tua untuk menjadi teladan yang baik pada anak contohnya dengan mengajak anak ke arena perjudian dan mengadakan arena perjudian di sekitar rumah.

Berdasarkan paparan hasil wawancara dan pencatatan dokumen tersebut beragam faktor yang mempengaruhi nilai pada kompetensi pengetahuan matematika menjadi rendah. Faktor tersebut adalah faktor yang bersumber dari dalam diri siswa (faktor internal) dan dari luar diri siswa (faktor eksternal)(Syukriani, 2013). Secara rinci faktor internal meliputi motivasi belajar, bakat, kecerdasan, minat dan perhatian, ketekunan, sikap, kebiasaan belajar, konsep diri, kelelahan, serta kondisi fisik. Faktor eksternal meliputi pola asuh orang tua, keadaan ekonomi, teman bergaul, kegiatan siswa dalam masyarakat, waktu sekolah, serta fasilitas sekolah (Slameto, 2013; Djaali, 2008). Walaupun siswa sudah belajar di sekolah namun pola asuh dan konsep diri tetap memiliki hubungan dengan keberhasilan siswa dalam belajar.

Siswa harus mendapat perhatian dari orang tuanya karena tugas orang tua tidak hanya menafkahi anak saja, namun sudah menjadi kewajiban bagi orang tua untuk mendidik anak-anak mereka semaksimal mungkin sehingga mampu menjadi generasi penerus yang baik(Vinayastri, 2015). Peran orang tua tidak hanya sekedar memberikan uang jajan atau menyekolahkan anak, tetapi juga ikut berperan dalam proses pendidikan anaknya(Reskia, 2014).“Orang tua berperan meletakkan dasar-dasar belajar pada anak mereka” (Rasinki dalam Khajehpour, 2011). Oleh karena itu, perlu adanya komunikasi yang dibangun orang tua dalam kehidupan sehari-hari dengan memperlihatkan contoh atau teladan dalam perilaku berupa ucapan-ucapan dan tindakan-tindakan yang lemah lembut dan menyenangkan (Sunarty, 2016). 
Teladan sikap orang tua sangat dibutuhkan bagi perkembangan anak karena anak-anak melakukan modeling dan imitasi dari lingkungan terdekatnya, karena itu pola asuh merupakan hal yang fundamental dalam pembentukan karakter serta mendorong anak untuk mau belajar sehingga mencapai hasil yang memuaskan (Adawiah, 2017).

Faktor eksternal berupa pola asuh diartikan sebagai bentuk kegiatan merawat, memelihara dan membimbing yang dilakukan oleh orang tua agar anaknya dapat mandiri, tumbuh dan berkembang secara sehat (Budiarnawan, 2014). Sikap orang tua dalam berinteraksi, membimbing, membina, dan mendidik dalam kehidupan sehari-hari menentukan kesuksesan anaknya menjalani kehidupan (Fitriyani, 2015). Oleh karena itu, pola asuh orang tua yang baik dapat mempengaruhi keberhasilan anak dalam belajar (Pakiding, 2016).

Selain pola asuh, faktor yang mempengaruhi keberhasilan belajar siswa adalah konsep diri. Konsep diri merupakan salah satu dari beberapa faktor internal yang dapat mempengaruhi pencapaian dalam belajar dan berinteraksi dengan orang lain. Interaksi yang dimaksudkan adalah adanya interaksi positif siswa dengan guru dalam proses belajar mengajar yang menjadi petunjuk kemampuan penyesuaian diri dari siswa sebagai sebuah pendukung tercapainya hasil belajar yang lebih baik(Effendi, 2004).Konsep diri memiliki pengaruh dalam menunjang kemampuan bersosialisasi di lingkungan keluarga, sekolah, dan masyarakat serta berperan sangat penting dalam pengembangan kepribadian dan peningkatan prestasi (Astawa, 2015). Konsep diri sebagai inti kepribadian merupakan aspek penting terhadap mudah tidaknya berhubungan dengan orang lain, sehingga mempunyai pengaruh yang cukup besar terhadap perilaku individu, yaitu individu bertingkah laku sesuai dengan konsep diri yang dimiliki (Ary, 2009).

Konsep diri terbentuk berdasarkan persepsi seseorang mengenai sikap-sikap orang lain terhadap dirinya dan semua bentuk kepercayaan, perasaan, dan penilaian yang diyakini individu tentang dirinya sendiri sehingga mempengaruhi proses interaksi sosial dengan lingkungan sekitar (Pambudi, 2012). Konsep diri tidaklah langsung dimiliki ketika seseorang lahir di dunia melainkan suatu rangkaian proses yang terus berkembang dan membedakan individu satu dengan yang lainnya. Hal ini penting dalam pengintegrasian kepribadian, memotivasi tingkah laku yang pada akhirnya tercapainya kesehatan mental sehingga konsep diri menjadi sebuah gambaran tentang bagaimana individu itu sendiri berbeda dengan individu yang lainnya (Rola, 2016).

Berdasarkan paparan di atas, konsep diri dan pola asuh orang tua memiliki arti penting dalam meningkatkan atau menurunkan hasil pencapaian kompetensi pengetahuan siswa. Oleh karena itu, peneliti termotivasi untuk mengetahui hubungan antara pola asuh orang tua dan konsep diri dengan kompetensi pengetahuan matematika pada siswa kelas V SD Gugus I Kecamatan Baturiti Kabupaten Tabanan tahun pelajaran 2018/2019.

\section{Metode}

Berdasarkan karakteristik masalah yang diteliti, penelitian ini merupakan jenis penelitian ex post facto. Penelitian ex post facto adalah suatu penelitian yang dilakukan untuk meneliti peristiwa yang telah terjadi dan kemudian melihat ke belakang untuk mengetahui faktor-faktor yang dapat menimbulkan kejadian tersebut, secara singkat dapat diartikan bahwa penelitian ex post facto merupakan penelitian setelah kejadian(Rahmawati, 2014). Penelitian ex post facto juga dikatakan suatu pendekatan pada subjek penelitian untuk meneliti yang telah dimiliki oleh subyek penelitian secara wajar tanpa adanya usaha sengaja memberikan perlakuan untuk memunculkan variabel yang telah diteliti (Dantes, 2012).Pada penelitian ini terdapat variabel bebas dan variabel terikat, yaitu pola asuh orang tua $\left(\mathrm{X}_{1}\right)$ sebagai variabel bebas pertama dan konsep diri $\left(\mathrm{X}_{2}\right)$ sebagai variabel bebas ke dua, sedangkan kompetensi pengetahuan matematika (Y) sebagai variabel terikat. Adapun desain penelitian bersumber dari Koyan, 2012:79, untuk lebih jelasnya dapat dilihat pada Gambar 1. 


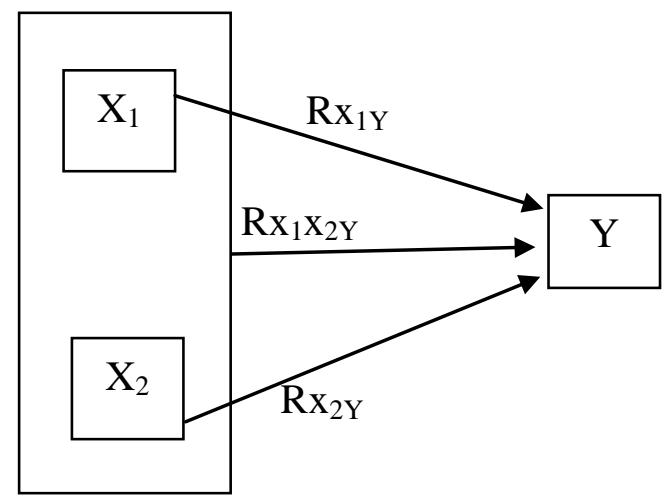

Gambar 1

Rancangan penelitian

Populasi dalam penelitian ini adalah seluruh siswa kelas V di Gugus I Kecamatan Baturiti, Kabupaten Tabanan tahun pelajaran 2018/2019 yang terdiri dari 7 SD. Dalam penelitian ini sampel yang diambil menggunakan teknik proportional random sampling. "Proporsional sampel merupakan jumlah sampel yang diambil dari setiap strata sebanding, sesuai dengan proporsional ukurannya"(Siregar, 2013). Prosedur yang ditempuh dilakukan dengan cara mengambil individu yang terdapat dalam masing-masing kategori populasi, sesuai dengan proporsi atau perimbangan untuk dijadikan sampel penelitian. Penentuan ukuran sampel sesuai dengan yang tertera pada Tabel Isaac dan Michael pada taraf signifikansi $5 \%$ tabel data populasi dan sampel untuk memudahkan dalam perhitungannya. Diketahui jumlah populasi pada penelitian ini sebesar 144 siswa, maka jumlah sampel yang dapat digunakan menurut Tabel Isaac dan Michael adalah sebesar 100 siswa. Setelah didapat jumlah sampel dari populasi kemudian dicari tiaptiap sampel dari sebaran populasi dengan rumus proporsional. Setelah mendapatkan jumlah sampel di tiap-tiap sekolah, maka langkah selanjutnya adalah menentukan individu-individu yang menjadi anggota sampel dengan teknik random.

Data kompetensi pengetahuan matematika diperoleh melalui pencatatan dokumen, sedangkan data pola asuh orang tua dan konsep diri dalam penelitian ini dikumpulkan dengan metode kuesioner. Dimensi yang digunakan pada pola asuh orang tua dalam penelitian ini adalah pola asuh otoriter, pola asuh permisif dan pola asuh demokratis, sedangkan dimensi yang digunakan pada konsep diri dalam penelitian ini adalah konsep diri fisik, konsep diri akademis, dan konsep diri sosial. Adapun kuesioner dalam penelitia ini menggunakan pola skala likert dengan jumlah masing-masing item yang digunakan untuk pola asuh orang tua dan konsep diri adalah 25 item pernyataan. 25 item pernyataan pola asuh orang tua termasuk pada kategori tinggi dengan $r_{11}=0,77$, sedangkan konsep diri termasuk pada kategori sangat tinggi dengan $r_{11}=0,84$. Kategori ini diperoleh dari hasil hitung reliabilitas yang dibandingkan dengan derajat reliabilitas. Selanjutnya, data dianalisis dengan teknik statistik deskriptif dan statistik inferensial. Uji prasyarat analisis regresi adalah uji normalitas, uji linieritas, dan uji multikolinieritas. Setelah uji prasyarat terpenuhi, berikutnya dilakukan uji hipotesis menggunakan regresi sederhana untuk uji hipotesis I dan II dan regresi ganda untuk uji hipotesis III. Data dianalisis dengan bantuan SPSS versi 17 for Windows.

\section{Hasil dan pembahasan}

Berdasarkan hasil analisis diketahui bahwa rata-rata data pola asuh orang tua termasuk ke dalam kategori baik/tinggi, yaitu 97,41 yang berada pada rentangan skor 83,35 $\leq \mathbf{M} \leq 100,05$. Rata-rata data konsep diri termasuk ke dalam kategori baik/tinggi, yaitu 98,35 yang berada pada rentangan skor $83,35 \leq \mathrm{M} \leq 100,05$. Rata-rata data kompetensi pengetahuan matematika termasuk ke dalam kriteria kurang, yaitu 62,75 yang berada pada rentangan skor $40-64$.

Uji hipotesis dalam penelitian ini menggunakan teknik analisis regresi sederhana dengan menggunakan rumus korelasi product moment dengan (variabel $\mathrm{X}_{1}$ dengan $\mathrm{Y}$ dan $\mathrm{X}_{2}$ dengan $\mathrm{Y}$ ) serta analisis regresi ganda atau korelasi ganda (analisis antara variabel $\mathrm{X}_{1}, \mathrm{X}_{2}$ dengan $\mathrm{Y}$ ). Sebelum uji hipotesis, terlebih dahulu dilakukan uji prasyarat. Pengujian prasyarat yang dilakukan meliputi uji normalitas sebaran data, uji linieritas, dan uji multikolinieritas.

Setelah uji prasyarat analisis terpenuhi dilakukan uji hipotesis. Adapun hasilnya, berdasarkan analisis yang dilakukan pada uji hipotesis I diperoleh nilai koefisien korelasi pola asuh orang tua dengan 
kompetensi pengetahuan matematika pada tabel correlations yaitu 0,570 dan nilai $R$ Square pada model summary adalah 0,325 . Hal ini berarti kontribusi pola asuh orang tua terhadap kompetensi pengetahuan matematika adalah 32,5\% sedangkan 67,5\% dipengaruhi oleh faktor luar. Untuk menguji nilai koefisien korelasi ini signifikan atau tidak signifikan mengunakan uji signifikansi (uji-t). Hasil analisis koefisien uji signifikansi (uji-t) pada tabel coefficients adalah sebesar 6,866 dan signifikansi sebesar 0,000. Berdasarkan kriteria uji signifikansi (uji-t) ternyata probabilitas (signifikansi) < 0,05 maka $\mathrm{H}_{0}$ ditolak dan $\mathrm{H}_{1}$ diterima. Hal ini berarti terdapat hubungan yang positif dan signifikan pola asuh orang tua dengan kompetensi pengetahuan matematika pada siswa kelas V SD di Gugus I Kecamatan Baturiti tahun pelajaran 2018/2019, dengan nilai koefisien korelasi yaitu 0,570 dan nilai koefisien determinasinya $32,5 \%$.

Untuk mengetahui persamaan regresinya dapat dilihat di tabel coefficients. Berdasarkan tabel tersebut diperoleh nilai a (constant) yaitu 37,744 dan nilai b (B) $\mathrm{X}_{1}$ yaitu 0,257 sehingga persamaan garis regresi untuk hipotesis I adalah $\hat{Y}=37,744+0,257 \mathrm{X}_{1}$. Persamaan ini menunjukkan bahwa nilai koefisien kompetensi pengetahuan matematika sebesar 37,744 tanpa adanya pengaruh dari pola asuh orang tua sedangkan nilai koefisien pola asuh orang tua $\left(X_{1}\right)$ yaitu 0,257 yang berarti apabila nilai pola asuh orang tua meningkat satu satuan maka nilai kompetensi pengetahuan matematika meningkat sebesar 0,257 satuan. Selain itu, akan dipaparkan juga hasil analisis untuk masing-masing jenis pola asuh orang tua yaitu otoriter, permisif, dan demokratis dengan kompetensi pengetahuan matematika siswa

Berdasarkan analisis yang dilakukan untuk uji hipoteisi II diperoleh nilai koefisien korelasi konsep diri dengan kompetensi pengetahuan matematika pada tabel correlations yaitu 0,502 dan nilai $R$ Square pada tabel model summary sebesar 0,252. Hal ini berarti kontribusi konsep diri terhadap kompetensi pengetahuan matematika adalah $25,2 \%$ sedangkan $74,8 \%$ dipengaruhi oleh faktor luar. Untuk menguji nilai koefisien korelasi ini signifikan atau tidak signifikan mengunakan uji signifikansi (uji-t). Hasil analisis koefisien uji signifikansi (uji-t) pada tabel coefficients yaitu 5,571 dan nilai signifikansi yaitu 0,000. Berdasarkan kriteria uji signifikansi (uji-t) ternyata probabilitas (signifikansi) < 0,05 maka $\mathrm{H}_{0}$ ditolak dan $\mathrm{H}_{1}$ diterima. Hal ini berarti terdapat hubungan yang positif dan signifikan konsep diri dengan kompetensi pengetahuan matematika pada siswa kelas V SD di Gugus I Kecamatan Baturiti tahun pelajaran 2018/2019, dengan nilai koefisien korelasi 0,502 dan nilai koefisien determinasinya 25,2\%. Untuk mengetahui persamaan regresi dapat dilihat pada tabel coefficients.

Berdasarkan tabel tersebut diperoleh nilai a (constant) yaitu 33,227 dan nilai b (B) $\mathrm{X}_{2}$ yaitu 0,300 sehingga persamaan garis regresi untuk uji hipotesis II adalah $\hat{Y}=33,227+0,300 X_{2}$. Persamaan ini menunjukkan bahwa nilai koefisien kompetensi pengetahuan matematika sebesar 33,227 tanpa adanya pengaruh dari konsep diri sedangkan nilai koefisien konsep diri (X2) yaitu 0,300 yang berarti apabila nilai konsep diri meningkat satu satuan maka nilai kompetensi pengetahuan matematika meningkat sebesar 0,300 satuan. Berdasarkan analisis yang dilakukan pada hipotesis III diperoleh nilai koefisien korelasi ganda pola asuh orang tua dan konsep diri dengan kompetensi pengetahuan matematika pada tabel model summary yaitu 0,741 dan nilai $R$ Square 0,549 . Hal ini berarti kontribusi secara bersama-sama pola asuh orang tua dan konsep diri terhadap kompetensi pengetahuan yaitu 54,9\%. Hasil output pada tabel ANOVA didapatkan nilai $F$ yaitu 59,035 dan nilai signifikasi yaitu 0,000. Nilai Ftabel diperoleh dari tabel distribusi f pada taraf signifikansi $5 \%$ dengan $F_{\text {tabel }}=(2 ; 98)$, maka menghasilkan nilai $F_{\text {tabel }} 3,09$.

Berdasarkan kaidah keputusan uji $\mathrm{F}$ ternyata $\mathrm{F}_{\text {hitung }}>\mathrm{F}_{\text {tabel }}$ yaitu 59,035 $>3,09$ sehingga $\mathrm{H}_{0}$ ditolak dan $\mathrm{H}_{1}$ diterima. Hal ini berarti terdapat hubungan yang positif dan signifikan antara pola asuh orang tua dan konsep diri dengan kompetensi pengetahuan matematika pada siswa kelas V SD di Gugus I Kecamatan Baturiti tahun pelajaran 2018/2019, dengan nilai koefisien korelasi yaitu 0,741 dan nilai koefisien determinasi yaitu 54,9\%. Untuk mengetahui persamaan regresinya dapat dilihat pada tabel coefficients. Berdasarkan tabel tersebut diperoleh nilai a sebesar 10,952 , b $X_{1}$ sebesar 0,246 , dan b $X_{2}$ sebesar 0,283 sehingga persamaan garis regresi untuk uji hipotesis III adalah $\hat{Y}=10,592+0,246 X_{1}+0,283 X_{2}$. Persamaan ini menunjukkan bahwa nilai koefisien kompetensi pengetahuan matematika sebesar 10,592 tanpa adanya pengaruh dari pola asuh orang tua dan konsep diri sedangkan nilai koefisien pola asuh orang tua $\left(\mathrm{X}_{1}\right)$ yaitu 0,246 yang berarti apabila nilai pola asuh orang tua meningkat satu satuan maka nilai kompetensi pengetahuan matematika meningkat sebesar 0,246 satuan dengan nilai koefisien konsep diri konstan dan apabila nilai konsep diri $\left(\mathrm{X}_{2}\right)$ yaitu 0,283 yang berarti ketika nilai konsep diri meningkat satu satuan maka nilai kompetensi pengetahuan matematika meningkat sebesar 0,283 satuan dengan nilai koefisien pola asuh orang tua konstan.

Untuk mengetahui berapa persen (\%) sumbangan efektif (SE) dan sumbangan relatif (SR) yang diberikan masing-masing variabel bebas yaitu pola asuh orang tua $\left(\mathrm{X}_{1}\right)$ dan konsep diri $\left(\mathrm{X}_{2}\right)$ dengan variabel terikat kompetensi pengetahuan matematika (Y) dilakukan perhitung. Untuk mempermudah melakukan perhitungan SE dan SR oleh karena itu perlu diketahui terlebih dahulu nilai korelasi dan 
regresinya. Nilai ini dapat dilihat pada tabel coefficients. Berdasarkan tabel tersebut diperoleh nilai koefisien regresi (beta) yaitu 0,545 $\left(\mathrm{X}_{1}\right)$ dan 0,474 $\left(\mathrm{X}_{2}\right)$ serta nilai koefisien korelasi yaitu 0,570 $\left(\mathrm{X}_{1}\right)$ dan $0,502\left(\mathrm{X}_{2}\right)$. Berdasarkan hasil perhitungan dapat diketahui bahwa sumbangan efektif (SE) pola asuh orang tua terhadap kompetensi pengetahuan matematika yaitu 31,1\%. Sementara itu untuk sumbangan efektif (SE) konsep diri terhadap kompetensi pengetahuan yaitu 23,8\%. Dengan total SE adalah sebesar 54,9\% atau sama dengan koefisien determinasi (R square) analisis regresi yakni 54,9\%. Berdasarkan hasil perhitungan sumbangan relatif (SR) diketahui bahwa sumbangan relatif pola asuh orang tua terhadap kompetensi pengetahuan matematika yaitu 56,6\%. Sementara sumbangan relatif (SR) konsep diri terhadap kompetensi pengetahuan matematika yaitu 43,4\%. Untuk total sumbangan relatif (SR) adalah $100 \%$ atau sama dengan 1.

Bersumber pada hasil analisis yang telah dilakukan, dalam penelitian ini ditemukan korelasi yang positif dan signifikan yang berarti semakin tinggi pola asuh orang tua siswa maka semakin tinggi pula pencapaian kompetensi pengetahuan matematika siswa. Sumbangan variabel pola asuh orang tua yang diberikan siswa terhadap pecapaian kompetensi matematika sebesar 32,5\%.

Hasil penelitian ini sejalan dengan penelitian terdahulu dari hasil penelitian Rahmawati (2014) menyatakan terdapat hubungan antara pola asuh orang tua dengan prestasi belajar siswa. Tinggi rendahnya pencapaian kompetensi pengetahuan matematika siswa bergantung pada pola asuh yang diterapkan orang tua di rumah. Hal ini didukung oleh pendapat Budang, (2017)yang menyatakan bahwa pola asuh orang tua merupakan salah satu faktor yang dapat mempengaruhi pencapaian hasil belajar siswa. Siswa yang memeroleh pola asuh yang baik dari kedua orang tuanya cenderung memiliki kebiasaan-kebiasan yang baik dalam kehidupan kesehariannya. Dengan demikian sangat penting bagi orang tua untuk memperhatikan pola asuh yang diberikan pada anak.

Hasil penelitian ini temukan bahwa pola asuh demokratis paling banyak memberikan sumbangan atau berkontribusi paling tinggi. Hal ini ditunjukkan dai besar kontribusi pola asuh demokratis terhadap kompetensi pengetahuan matematika yaitu 51,2\%. Sedangkan kontirbusi pola asuh otoriter terhadap kompetensi pengetahuan matematika sebesar 32,8\% dan kontribusi pola asuh permisif terhadap kompetensi pengetahuan matematika sebesar 49,3\%. Jadi hasil penelitian ini menunjukkan bahwa anak yang dididik dengan pola asuh demokratis memiliki dampak positif untuk perkembangan dan kepribadian anak, sehingga mengacu anak untuk memeroleh hasil kompetensi pengetahuan yang memuaskan. Hasil penelitian ini didukung oleh Yusniyah (2008) yang menunjukkan fakta bahwa orang tua memegang peranan penting dalam perkembangan belajar anak dan sangat besar pengaruhnya terhadap tinggi rendahnya pencapaian belajar anak di sekolah. Penerapan pola asuh demokratis dapat meningkatkan hasil belajar siswa, karena dengan penerapan pola asuh demokratis dapat membantu siswa tumbuh dengan baik sehingga mengacu pada kompetensi pengetahuannya. Hal ini didukung oleh penelitian Lestari (2015) yang mendapatkan hasil bahwa siswa yang dididik dengan pola asuh demokratis memiliki kemampuan prestasi belajar yang lebih tinggi dibandingkan dengan pola asuh permisif dan pola asuh otoriter.

Orang tua mempunyai peran penting terhadap anaknya untuk mencapai kompetensi pengetahuan matematika yang maksimal. Matematika merupakan salah satu mata pelajaran yang tertuang dalam kurikulum dan seringkali dianggap sebagai barometer prestasi peserta didik. Keberhasilan siswa dalam mempelajari suatu bahan pelajaran matematika akan sangat mendukung penguasaan bahan pelajaran selanjutnya. Hal ini dikarenakan matematika merupakan bidang studi yang memerlukan banyak pemikiran, pemahaman, dan kemandirian dalam belajar sehingga perlu adanya kontrol diri dan pemupukan tanggung jawab sejak dini pada anak. Oleh karena itu, Penting bagi orang tua untuk memperhatikan pola asuh yang diterapkan kepada anak-anaknya agar dapat memberikan kontribusi positif bagi perkembangan anak dan pencapaiannya pada kompetensi pengetahuan matematika.

Orang tua dengan pola pengasuhan permisif artinya pemanja anak, yaitu orang tua yang membebaskan anak untuk melakukan sesuatu sesuai kehendaknya sehingga pola asuh permisif kurang baik dalam membentuk karakter dan tanggung jawab anak selain itu juga menunjukkan prestasi yang kurang (Hetherington dalam Karnangsyang, 2017). Hal ini berimbas pada pencapaian kompetensi matematika yang belum optimal. Sejalan dengan hal ini, didukung oleh penelitian yang dilakukan oleh Najibah (2017) yang menyampaikan bahwa apabila orang tua terus meningkatkan pola asuh permisifnya hal ini akan berdampak pada semakin menurunya hasil belajar anak. Dibuktikan dari hasil analisis yang dilakukan diperoleh informasi bahwa antara pola asuh permisif dengan hasil belajar berkorelasi negatif yang lemah.

Orang tua dengan pola pengasuhan otoriter adalah orang tua yang menuntut anaknya untuk menurut dengan memaksa, memberikan hukuman, mengontrol, mengevaluasi prilaku dan tindakan anak agar sesuai dengan aturan standar (Hetherington dalam(Karnangsyang, 2017). Apabila orang tua menerapkan pola asuh otoriter dengan memberikan kontrol dan evaluasi pada setiap kegiatan yang 
dilakukan anak untuk tujuan kesuksesan anak maka hal tersebut dapat memberikan dampak positif bagi pencapaian kompetensi pengetahuan matematika siswa. Hal ini juga didukung oleh hasil penelitian yang dilakukan oleh Najibah (2017) yang diketahui bahwa pola asuh otoriter berkorelasi positif dengan hasil belajar siswa namun termasuk pada kategori lemah.

Oleh karena itu, pola pengasuhan yang tepat terhadap pendidikan anak merupakan aspek yang sangat penting bagi perkembangan anak untuk mencapai hasil yang maksimal (Tocu, 2014). Hasil ini didukung dengan pendapat Purwanto (2007) yang menyatakan bahwa dimana dukungan, suasana dan keadaan keluarga turut menentukan hasil belajar anak. Begitu pula orang tua tetap harus memberikan perhatian, bimbingan, pengawalan dan sikap yang positif untuk peningkatan prestasi akademik anak-anak mereka khususnya pada mata pelajaran matematika (Ismail, 2017). Sikap yang baik dan pola pengasuhan yang tepat dari orang tua dalam mengajar dan mendidik anak-anak mereka, maka anaknya pun menjadi baik dan terdidik.

Berdasarkan hasil analisis dan temuan dalam penelitian lain yang sesuai dengan penelitian ini, dapat disimpulkan bahwa terdapat hubungan yang positif dan signifikan pola asuh orang tua dengan kompetensi pengetahuan matematika pada siswa kelas V SD di Gugus I Kecamatan Baturiti tahun pelajaran 2018/2019.

Bersumber pada hasil analisis yang telah dilakukan, dalam penelitian ini ditemukan korelasi yang positif dan signifikan yang berarti semakin tinggi konsep diri siswa maka semakin tinggi pula pencapaian kompetensi pengetahuan matematika siswa. Sumbangan variabel konsep diri yang diberikan siswa terhadap pencapaian kompetensi pengetahuan matematika sebesar $25,2 \%$.

Hasil penelitian ini sejalan dengan penelitian terdahulu dari hasil penelitian Parnata (2014) menyatakan terdapat hubungan antara konsep diri dengan hasil belajar matematika. Konsep diri merupakan salah satu faktor internal yang mempengaruhi siswa dalam mencapai hasil belajar yang baik. Penelitian yang dilakukan oleh Siew-Fun Tang (2011) menyatakan hal yang sama yaitu ada hubungan yang erat antara konsep diri dengan prestasi akademik. Hal ini senada dengan pendapat Effendi (2014) yang menyatakan bahwa konsep diri diyakini dapat mempengaruhi prestasi belajar sebab dengan evaluasi diri mengenai kemampuan dan perilakunya maka lebih optimis untuk menunjukkan prestasi hasil kemampuannya itu. Begitu pula hasil penelitian yang dilakukan oleh Arefi pada tahun 2014 dengan judul "The Relation Between Academic Self Concept and Academic Motivation and Its Effect On Academic Achievement" yang menunjukkan hasil konsep diri akademik secara positif dan signifikan berbuhungan dengan motivasi akademik dan prestasi akademik siswa.

Memiliki konsep diri yang baik/positif memberikan dampak yang positif pada kompetensi pengetahuan siswa, sebaliknya jika memiliki konsep diri yang buruk/negatif maka berdampak buruk pula pada pencapaian kompetensi pengetahuanya. Sejalan dengan Sutoyo (2009:280) yang menyampaikan bahwa konsep diri adalah pandangan menyeluruh tentang totalitas diri baik positif maupun negatif terhadap diri sendiri. Apabila seorang anak memiliki konsep diri yang positif terhadap kemampuan dirinya, ia tidak cemas atau takut menghadapi suatu kegagalan. Ia mempunyai keyakinan akan kemampuan dirinya sendiri sehingga ia tidak takut melakukan kesalahan, karena yang terpenting baginya adalah bagaimana dirinya mampu menghadapi masalah. Dengan demikian konsep diri yang positif tersebut akan sangat mempengaruhi motivasi belajarnya yang pada akhirnya akan mempengaruhi kompetensi pengetahuan siswa.

Berdasarkan hasil analisis dan temuan dalam penelitian lain yang sesuai dengan penelitian ini, dapat disimpulkan bahwa terdapat hubungan yang positif dan signifikan konsep diri dengan kompetensi pengetahuan matematika pada siswa kelas V SD di Gugus I Kecamatan Baturiti tahun pelajaran $2018 / 2019$.

Bersumber pada hasil analisis yang telah dilakukan, dalam penelitian ini ditemukan hubungan yang positif dan signifikan yang berarti semakin tinggi pola asuh orang tua dan konsep diri maka semakin tinggi pula pencapaian kompetensi pengetahuan matematika siswa. Sumbangan pola asuh orang tua dan konsep diri terhadap kompetensi pengetahuan matematika sebesar 54,9\%.

Hasil penelitian ini sejalan dengan penelitian terdahulu dari hasil penelitian Budiarnawan (2014) yaitu konsep diri dan pola asuh orang tua memiliki hubungan yang positif dan signifikan terhadap hasil belajar siswa. Hasil penelitian dari Rahmawati (2014) menyatakan hal yang senada pada pola asuh orang tua yaitu terdapat hubungan antara pola asuh orang tua dengan prestasi belajar siswa. Hasil penelitian dari Parnata (2014) menyatakan terdapat hubungan antara konsep diri dengan hasil belajar matematika. Oleh karena itu, pola asuh orang tua dan konsep diri memiliki hubungan yang positif dan signifikan secara bersama-sama terhadap hasil belajar siswa. Tinggi rendahnya pola asuh orang tua dan konsep diri berhubungan dengan pencapaian belajar siswa. Hal ini didukung oleh pendapat Budang (2017) yang menyatakan bahwa pola asuh orang tua merupakan salah satu faktor yang dapat mempengaruhi 
pencapaian hasil belajar siswa. Begitu pula yang di sampaikan oleh Effendi (2014) bahwa konsep diri juga mempengaruhi prestasi belajar sebab dengan evaluasi diri mengenai kemampuan dan perilakunya maka lebih optimis untuk menunjukkan prestasi hasil kemampuannya itu. Oleh karena itu konsep diri juga mempunyai peranan yang sangat penting (Astawa et al., 2015).

Siswa yang dengan pola asuh yang baik dari kedua orang tuanya cenderung memiliki kebiasaankebiasan yang baik dalam kehidupan kesehariannya. Pola asuh yang dapat diterapkan adalah pola asuh demokratis. Penerapan pola asuh demokratis dapat meningkatkan hasil belajar siswa, karena dengan penerapan pola asuh demokratis dapat membantu siswa tumbuh dengan baik sehingga mengacu pada kompetensi pengetahuannya. Hal ini didukung oleh penelitian Lestari (2015) yang mendapatkan hasil bahwa siswa yang dididik dengan pola asuh demokratis memiliki kemampuan prestasi belajar yang lebih tinggi dibandingkan dengan pola asuh permisif dan pola asuh otoriter. Hasil ini sesuai dengan pendapat Purwanto (2010) yang menyatakan dimana dukungan, suasana dan keadaan keluarga turut menentukan hasil belajar anak. secara umum siswa memperoleh pola asuh yang baik dari kedua orang tuanya, cenderung memiliki kebiasaan atau pola tingkah laku yang baik dalam kesehariannya. Pola tingkah laku yang dimaksud adalah penyesuaian diri dengan situasi serta bagaimana dapat menjadikanya sebagai kebiasaan yang positif. Melalui pembiasaan berpola tingkah laku yang positif dapat memberikan sumbangan yang positif pada konsep diri anak. Dengan demikian sangat penting bagi orang tua untuk memperhatikan pola asuh yang diberikan pada anak dan konsep diri yang positif dalam diri siswa itu sendiri sebagai bahan evaluasi untuk meningkatkan hasil belajarnya pada kompetensi pengetahuan matematika.

Berdasarkan hasil analisis dan temuan dalam penelitian lain yang sesuai dengan penelitian ini, dapat disimpulkan bahwa terdapat hubungan yang positif dan signifikan antara pola asuh orang tua dan konsep diri dengan kompetensi pengetahuan matematika pada siswa kelas V SD di Gugus I Kecamatan Baturiti tahun pelajaran 2018/2019.

\section{Simpulan dan saran}

Berdasarkan hasil penelitian dan analisis data statistik, maka dapat disimpulkan sebagai berikut, (1) terdapat hubungan yang positif dan signifikan pola asuh orang tua dengan kompetensi pengetahuan matematika siswa kelas V SD di Gugus I Kecamatan Baturiti tahun ajaran 2018/2019, dengan nilai koefisien korelasi yaitu 0,570 dan nilai koefisien determinasi 32,5\%, (2) terdapat hubungan yang positif dan signifikan konsep diri dengan kompetensi pengetahuan matematika siswa kelas V SD di Gugus I Kecamatan Baturiti tahun ajaran 2018/2019 dengan nilai koefisien korelasi yaitu 0,502 dan nilai koefisien determinasi yaitu 25,2\%, (3) terdapat hubungan yang positif dan signifikan antara pola asuh orang tua dan konsep diri dengan kompetensi pengetahuan matematika siswa kelas V SD di Gugus I Kecamatan Baturiti tahun ajaran 2018/2019 dengan nilai koefisien korelasi yaitu 0,741, nilai koefisien determinasi yaitu 54,9\%, dan sumbangaan efektif dari masing-masing variabel bebas terhadap variabel terikat yaitu $31,1 \%$ untuk pola asuh orang tua dan $23,8 \%$ untuk konsep diri.

\section{Daftar Rujukan}

Adawiah, R. (2017). Pola Asuh Orang Tua dan Implikasinya Terhadap Pendidikan Anak. Jurnal Pendidikan Kewarganegaraan, 7(1), 33-48.

Ary, W. Bin, \& Dian Ratna Sawitri, T. R. A. (2009). Hubungan Konsep Diri dengan Penyesuaian Sosial Siswa Kelas Akselerasi di SMP Negeri 2 dan SMP PL Domenico Savio Semarang. Fakultas Psikologi Universitas Diponegoro, 1-12.

Astawa, I. M. W., Sadia, W., \& Suastra, W. (2015). Pengaruh Model Pembelajaran Berbasis Proyek Terhadap Sikap Ilmiah Dan Konsep Diri Siswa Smp. E- Journal Program Pascasarjana Universitas Pendidikan Ganesha, 5.

Budang, P. (2017). Korelasi Pola Asuh Orang Tua dengan Hasil Belajar Matematika Pada Siswa Kelas IV SD Negeri 5 Tengadak. Jurnal Pendidikan Dasar Perkhasa, 3(2), 349-356.

Budiarnawan, K. A., Antari, N. N. M., \& Rati, N. W. (2014). Hubungan antara konsep diri dan pola asuh orang tua terhadap hasil belajar IPA siswa kela V SD di desa Selat. Jurnal Mimbar PGSD Universitas Pendidikan Ganesha, 2(1).

Dantes, N. (2012). Metode Penelitian. Yogyakarta: CV ANDI OFFSET.

Dipayana, I. M. D. (2014). Pengaruh Strategi Pembelajaran Rotating Trio Exchange (RTE) terhadap Hasil 
Belajaran Matematika. Jurnal Mimbar PGSD Universitas Pendidikan Ganesha, 2(1).

Djaali, H. (2008). Psikologi Pendidikan. Jakarta: Bumi Akasa.

Effendi, K. (2004). Hubungan Antara Konsep Diri dan Kemampuan Verbal dengan Prestasi Belajar Pada Siswa Kelas Lima Sekolah Dasar Muhammadiyah Sukonandi Yagyakarta. Jurnal Psikologi Indonesia, 1(1), 26-31.

Fathani, A. H. (2016). Pengembangan Literasi Matematika Sekolah dalam Persspektif Multiple Intelegences. EduSains, 4(2), 136-150.

Fitriyani, L. (2015). Peran pola asuh orang tua dalam mengembangkan kecerdasan emosi anak. Lentera, XVIII(1), 93-110.

Ismail, W. (2017). Pengaruh Pola Asuh Orangtua Terhadap Prestasi Akademik Mahasiswa. Lentea Pendidikan, 20(1), 54-69.

Japa, I .G.N dan Suarjana, I. M. (2015). Pendidikan Matematika 1. Singaraja: Universitas Pendidikan Ganesha.

Karnangsyang, E. (2017). Hubungan Pola Asuh Orang Tua dengan Hasil Belajar dan Implikasinya Terhadap Pelayanan Bimbingan dan Konseling. Jurnal Pendidikan Indonesia, 3(1), 1-9.

Khajehpour, M. (2011). Relationship Between Emotional Intelligence, Parental Involvement And Academic Performance Of High School Students. Science Direct, 3.

Kosasih. (2014). Strategi Belajar dan Pembelajaran. Bandung: Yrama Widya.

Pakiding, S. (2016). Pengaruh Pola Asuh Orang Tua dan Lingkungan Sekolah Terhadap Hasil Belajar Matematika Melalui Motivasi Belajar Siswa SMK Negeri Kecamatan Samarinda Utara. Jurnal Pendas Mahakam, 1(2), 237-249.

Pambudi, P. S. (2012). Hubungan Konsep Diri dengan Prestasi Akademik pada Mahasiswa Keperawatan. Jurnal Nursing Studies, 1(1), 149-156.

Purwanto, N. (2010). Prinsip-Prinsip dan Teknik Evaluasi (1st ed.). Jakarta: KENCANA.

Rahmawati, F. (2014). Hubungan Antara Pola Asuh Orang Tua dan Kebiasaan Belajar terhadap Prestasi Belajar Siswa SD Kelas IV Semester Genap di Kecamatan Melaya-Jembrana. Jurnal Mimbar PGSD Universitas Pendidikan Ganesha, 2(1).

Reskia, S. dan H. (2014). Pengaruh Tingkat Pendidikan Orang Tua terhadap Prestasi Belajar Siswa di SDN Inpres 1 Birobuli. Elementary School of Education E-Journal, 2(4), 82-93.

Rola, F. (2016). Hubungan konsep diri dengan motivasi berprestasi pada remaja. USU Repository.

Siregar, S. (2013). Metode Penelitian Kuantitatif. Jakarta: Kencana Predana Media Group.

Slameto. (2013). Belajar dan Faktor-faktor yang Mempengaruhinya. Jakarta: Rineka Cipta.

Sunarty, K. (2016). Hubungan pola asuh orangtua dan kemandirian anak. Journal of EST, 2(3), 152-160.

Susanto, A. (2013). Teori Belajar dan Pembelajaran di Sekolah Dasar. Jakarta: Kencana Predana Media Group.

Syukriani, A. (2013). Model Struktural dalam Menilai Antar-Hubungan antara Faktor Internal dan Faktor Eksternal terhadap Prestasi Belajar Matematika Siswa Kelas X SMA Negeri di Kota. Jurnal Sainsmat, II(1).

Tocu, R. (2014). Study on the parental beliefs and attitudes towards child rearing and education. Procedia - Social and Behavioral Sciences, 137, 153-157. https://doi.org/10.1016/j.sbspro.2014.05.268

Vinayastri, A. (2015). Pengaruh Pola Asuh (Parenting) Orang-Tua Terhadap Perkembangan Otak Anak Usia Dini. Jurnal Ilmiah Widya, 3(33-42).

Yuda, G. P. I. dan N. D. dan M. S. (2013). Pengaruh Model Pembelajran Berbasis-Otak (Brain-Based Learning) Terhadap Hasil Belajar Matematika Siswa Kelas V SD Negeri di Desa Sinabun. Jurnal Mimbar PGSD Universitas Pendidikan Ganesha, 1(1). Retrieved from berbasis-otak (brain-based learning), hasil belajar matematika. 